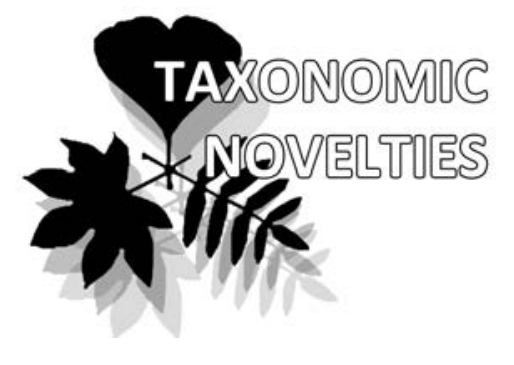

Vyacheslav Yu. Barkalov ${ }^{1 *}$

e-mail: barkalov@biosoil.ru

Pavel V. Krestov ${ }^{2}$

E-mail: krestov@botsad.ru

${ }^{1}$ Federal Scientific Center for the East Asia Terrestrial Biodiversity FEB RAS, Vladivostok, Russia

${ }^{2}$ Botanical Garden-Institute FEB RAS, Vladivostok, Russia

Manuscript received: 28.11 .2016 Review completed: 24.12 .2017 Accepted for publication: 12.01.2018

Published online: 09.04.2018

\section{A new species of Silene L. (Caryophyllaceae) from the Russian Far East}

\author{
Vyacheslav Yu. Barkalov ${ }^{1 *} \&$ Pavel V. Krestov ${ }^{2}$
}

\begin{abstract}
A B S T R A C T
This paper presents the description of a new species for science - Silene badzhalensis (Caryophyllaceae), belonging to the section Graminiformes Lazkov, from the Badzhal range in the southern part of the Russian Far East. This species is characterized by loose, densely branched caudex, few flowered (3-5 flowers) raceme, long thin pedicels, narrow white or slightly pinkish tinged petals with two coronal scales, and bright glabrous tubular-clavate calyx with 10 greenish veins, slightly swollen after flowering. It occurs at the ledges and crevices of rock outcrops within the forest belt (about $700 \mathrm{~m}$ above sea level).
\end{abstract}

K e y w o r d s : Caryophyllaceae, Silene, Badzhal'sky Mountain Range, Russian Far East

\section{P E 3 Ю M E}

Баркалов В.Ю., Крестов П.В. Новый виА рода Silene (Caryophyllaceае) с российского Аальнего Востока. Приводится описание нового ААя науки вила - Silene badzhalensis (Caryophyllaceae) с БаАжальского хребтта в южной части российского Аальнего Востока, отнесенного к секции Graminiformes Lazkov. Этот вил характеризуется рыхлыми дерновинками, малоцветковым (3-5 цветков) кистевидным соцветием, Алинными тонкими цветоножками, узкими белыми или слегка розоватыми лепестками с Авумя придатками и светлой голой трубчато-булавовилной чашечкой с 10 зеленоватыми жилками, слабо взАутой после цветения. Он приурочен к уступам и трещинам скал-останцев в лесном поясе (около 700 м наА уровнем моря).

К $\mathbf{\Lambda}$ ю че в ы е с $\mathbf{\Lambda} о$ в а: Caryophyllaceae, Silene, БаАжальский хребет, российский Аальний Восток
During botanical survey in July-August of 2016 in Badzhal'sky Mountain system in south-west of Khabarovsky Krai (Fig. 1), in the crevices of rock outcrop faced to the Yarap River valley, we found unknown species of Silene L. belonging to the section Graminiformes Lazkov (Lazkov 1997) that also includes Silene stenophylla Ledeb., S. chamarensis Turcz. and S. jenisseensis Willd. (Pavlova \& Bezdeleva 1996). Here we describe our finding as a species new for the science.

\section{Silene badzhalensis Barkalov et Krestov sp. nova}

Holotype: RUSSIA, "Khabarovsky Krai, Verkhnebureinsky district, Badzhal'sky Mountain Range, left bank of Yarap River, $10 \mathrm{~km}$ downstream from the confluence of its tributaries Levyi Yarap and Pravyi Yarap; dry rock cliffs on the mountain slope, in the forest belt; $50^{\circ} 15^{\prime} 43^{\prime \prime} \mathrm{N}$, 134²41'48"E; 2 Aug 2016, coll. V.Yu. Barkalov, n 331 (LE, isotypes - VLA, VBGI) (Fig. 2).

Description. Herbaceous perennial plants up to $30 \mathrm{~cm}$ in height; caudex densely branched, producing numerous short vegetative (sterile) shoots and several evenly leafy generative (culms ended with inflorescence) shoots, with twisted weathered basal leaves of the past years. Leaves of sterile shoots are linear-lanceolate to linear-oblanceolate, $4-13 \mathrm{~cm}$ long (with petiole) and 1.2-4 mm wide; base is attenuate into petioles, apex acuminate, both sides shallowly tubercular, margins scabrous to ciliate; petioles long, thin, ciliate, base connate and sheath-like. Stem leaves are in 4-6 pairs, linear-lanceolate, $2-12 \mathrm{~cm}$ in length, $0.5-3 \mathrm{~mm}$ in width, opposite, with short petioles at the base, scabrousciliate along the rim, often with shortened sterile shoots in axils. Pedicels are slender, $2-4 \mathrm{~cm}$ long, glabrous. Bracts are opposite, ovoid, 3-6 mm long; apex attenuate-acuminate; with ciliate margins. Flowers are in numbers 3-5, in loose, racemose inflorescence, solitary or paired (at the apex), not drooping, on deflected glabrous pedicels. Calyx tubularcampanulate, 11-15 $\mathrm{mm}$ long and 4-7 mm wide, light, with 10 greenish veins, glabrous; the lobes of the calyx are triangular-ovate, $2.5 \mathrm{~mm}$ long, acuminate at the apex, white-membranous and densely ciliate along the margins. Petals 1.5-1.8 cm long, deeply bilobate, with obtuse oblong lobes up to $3.5 \mathrm{~mm}$ long and $2 \mathrm{~mm}$ wide, pinkish-white; their claws in the upper part with two small $0.4-1 \mathrm{~mm}$ long scales, glabrous. Stamens are in number of 10 , exceed calyx in length, with purple oval anthers $1.5-1.7 \mathrm{~mm}$ long and with bare filaments. Styles are in number of 3; carpophores (ovary stalks) 3-4 mm long, densely short hairy. Capsule is oblong-obovate, 8-9 $\mathrm{mm}$ long, abruptly narrowed at apex. Seeds (not mature) are reniform, obtuse-tubercular.

Affinity. Silene bad₹halensis belongs to the section Graminiformes Lazkov and differs from the relevant species $S$. stenophylla Ledeb. by loose turfs, rosette withered leaves of 


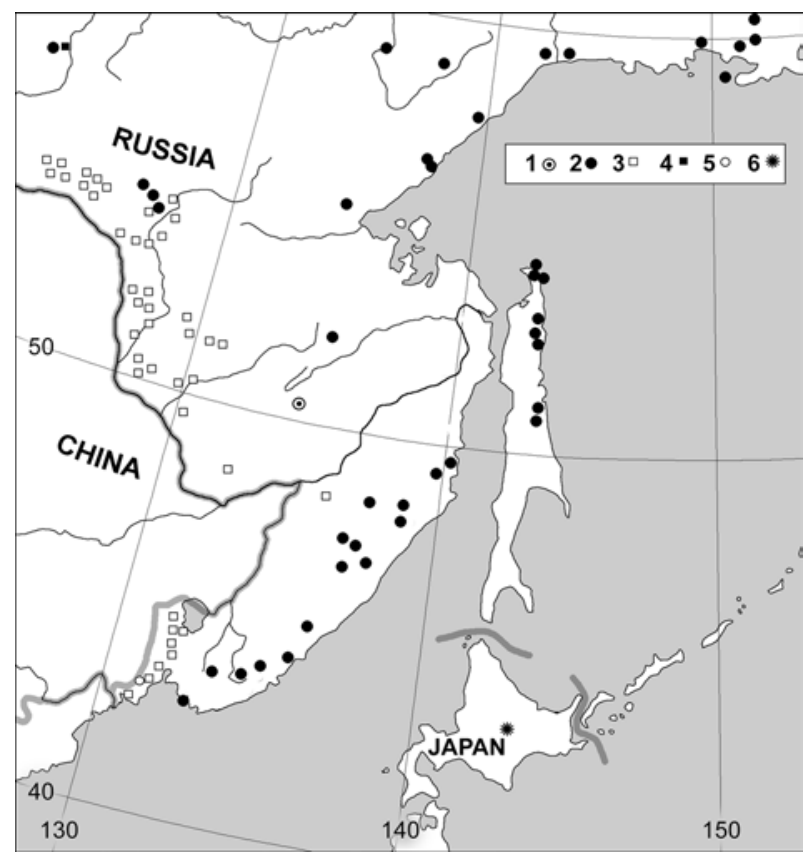

Figure 1 Location of the locus classicus for Silene badzhalensis Barkalov et Krestov (1) and distribution of close species of $S$. stenophylla (2), S. jenisseensis (3), S. chamarensis (4), S. oligantella (5) (2-5: according to Pavlova \& Bezdeleva 1996) and S. tokachiensis (6, according to Kadota 1994)

past years, preserved entirely in a twisted form (rather than breaking off up to the petioles), a large number of pairs (4-6, not 1-3) of cauline leaves, pale pinkish-white and narrower petals, narrower, slightly inflated after anthesis calyx with greenish veins (not purplish campanulate with dark veins). This species differs from $S$. chamarensis Turcz. by the lack of scaly-like appendages on the petioles of withered leaves on sterile shoots, longer pedicels $(2-4 \mathrm{~cm}$, not $0.5-$ $1.5 \mathrm{~cm}$ ), narrowly oblanceolate claws of petals (rather than obovate), acuminate coronal scales (rather than rounded). It differs from $S$. jenisseensis Willd. by multicrowned caudex, ciliate cauline leaves, few-flowered inflorescence (3-5, not more than 7 flowers), pedicels $2-3$ times longer than calyx (but not shorter), capsules 8-9 $\mathrm{mm}$ long (rather than 6-7 $\mathrm{mm}$ long).

Etymology. The species is named after the large mountain system it was found in - Badzhal Mountains.

Habitat. Specimens of Silene badð̧alensis was collected on the rock outcrops and rock crevices within forest belt at elevation of approximately $700 \mathrm{~m}$ above sea level. The species in its habitat is associated with Aizopsis middendorffianum (Maxim.) Grulich, Poa skvortrovii Prob., Orostachys spinosa (L.) C.A. Mey., Selaginella rupestris (L.) Spring.

Phenology. This species was collected in time of transition between flowering and fruiting that suggest July as a flowering time and August as fruiting time.

Distribution. This species is known only from locus classicus, but its new finds are possible both within the Badzhal mountain system, and on adjacent ridges, in similar habitats.

Notes. The systematics of Far Eastern species of the genus Silene L. remains unclear, and information on their distribution in the Russian Far East is not complete and re- quire additional studies. Distribution of typical (small-size) S. jenisseensis is limited to south Siberia (Altai and Sayans regions). The indication of this species by Kozhevnikov \& Kozhevnikova (1993) for the highlands of the Nyukzha floristic district is based on misidentification. Thorough identification of Nyukzha specimens made clear that they all belonged to $S$. chamarensis var. udocanica Peschkova. This species is widespread in the high mountains of the Altai-Sayans and Baikal region (Baikov 2005), and in the Far East occurs only high in the mountains of the Nyukzha district.

In the Zabaikalskii Territory region and in the south of the Russian Far East, especially in Dauria and in the south of Primorskii Territory, the forest-steppe race of S. jenissensis -S. jenissensis subsp. popovii Zuev is widespread. These are very large plants that do not form turf and differ from other populations by numerous small flowers and a thickened stem. The Far Eastern plants of this species differ strongly from the type race and probably deserve to be considered as a separate species.

The S. oliganthella Nakai with the main part of distribution range in the Korean peninsula was found only in one location in the south of Primorskii Territory (Lazkov 1998). This species was often attributed mistakenly to the $S$. jenissensis previously.

Kadota (1994) described S. tokachiensis Kadota, the endemic of Hokkaido closely related to S. stenophylla. Lazkov (1998) showed distribution of this species in the Sikhote-Alin and noted "the absence of scaly remains on the caudex and usually sticky stems" as its distinction. With reference to Lazkov (1998), this species is shown in Kozhevnikov \& Probatova (2006). However, the features showed by Lazkov (1998) for this species cannot be differential, because they are characteristic of many other species. Probably it was incorrect translation of the description given by Kadota (1994), who mentioned the shape of the corolla bracts and the presence of pronounced sclerotic appendages at the base of dilated petioles as a difference. At the same time, Kadota related Sakhalin and Okhotsk plants to the species $S$. stenophylla, cited the specimens studied, but apparently he had not analysed the Sikhote-Alin plants. Analysis of extensive herbarium material, made in this study, showed no any significant differences between the Sikhote-Alin plants and the Okhotsk plants of this group of Silene and allowed to confirm the big difference between these speciments and specimens from Hokkaido. Perhaps, the populations of Silene from the Sikhote-Alin Mountains represent a special southern race of $S$. stenophylla.

None of the three species noted above were ever mentioned for the Badzhal Mountains. Our specimens collected there combine the features of northern populations of S. stenophylla and western populations of $S$. chamarensis, and they both differ strongly from $S$. jenisseensis. The distribution of S. stenophylla is shown by Pavlova \& Bezdeleva (1996) for Bureinsky and Amgunsky floristic districts, and there is only one point on the distribution map (probably on Dusse-Alin Mountain Range; Pavlova \& Bezdeleva 1996: p. 106). Thus, the finding of $S$. badzhalensis essentially complements the general distribution pattern of Silene species of the section Graminiformes in northeast Asia. 


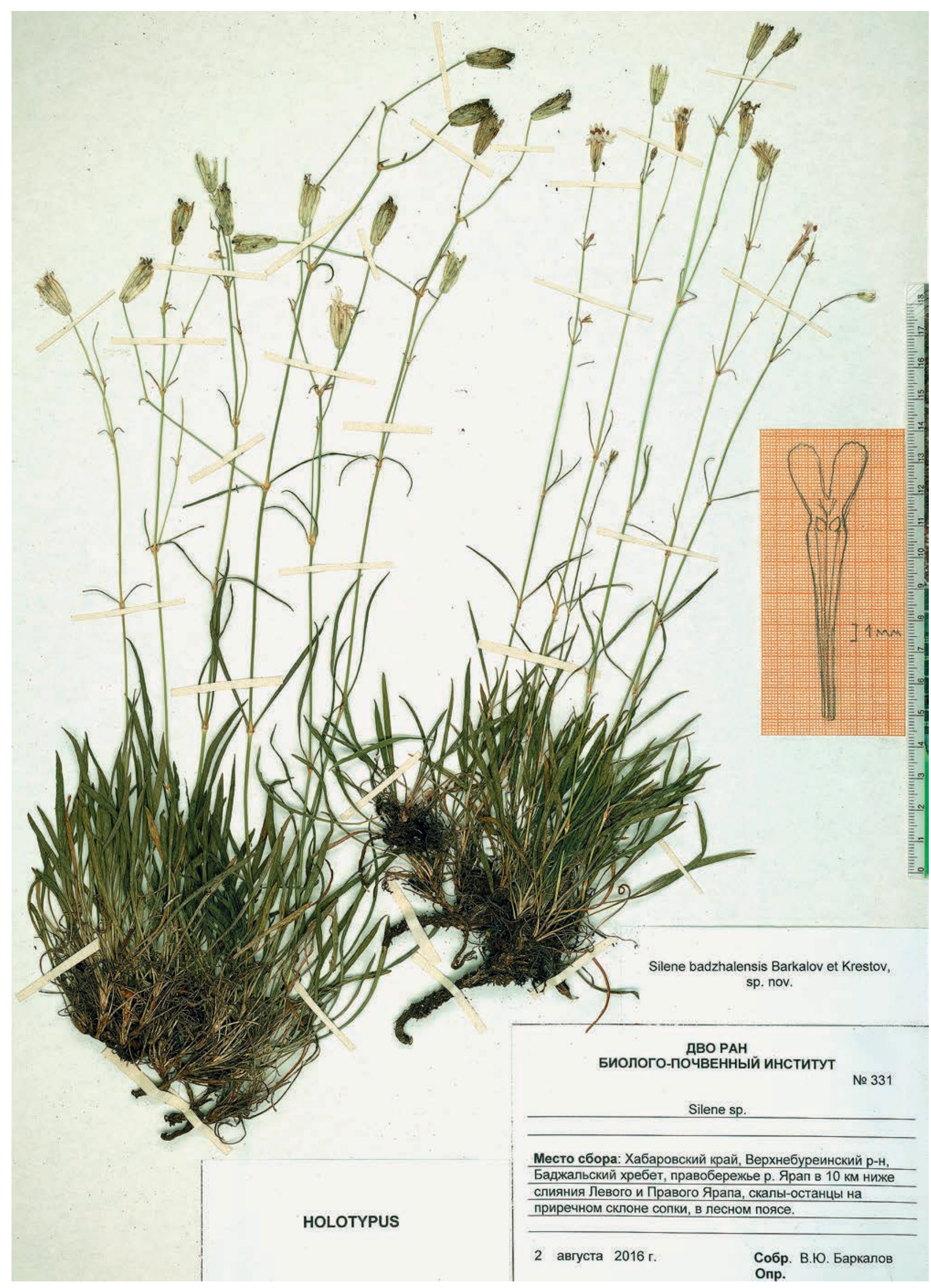

Figure 1 Holotype of Silene badzhalensis Barkalov et Krestov (Label: Institute of Biology and Soil Science; No. 331; Collected in: Khabarovsky Krai, Verkhnebureinsky district, Badzhal'sky Mountain Range, left bank of Yarap River, $10 \mathrm{~km}$ downstream of the confluence of its tributaries Levyi Yarap and Pravyi Yarap; dry rock outcrop on the mountain slope; in the forest belt; 2 Aug 2016; coll. V.Yu. Barkalov) 


\section{ACKNOWLEDGEMENTS}

We are grateful to the Far Eastern Branch of the Russian academy of sciences for financial support (Program “The Far East", grant No. 15-I-6-006 to Pavel Krestov).

\section{LITERATURE CITED}

Kadota, Y. 1994. New species of Silene (Caryophyllaceae) from Hokkaido, Japan. Memories of the National Science Museum (Tokyo) 27(1): 64-70.

Kozhevnikov, A.E. \& Kozhevnikova Z.V. 1993. Materials on the flora of Nyukaba floristic district (Amurskaya Territory). Preprint No. 1372-B93 of 26.03.1993. BiologoPochvenniy Institut DVO RAN, Vladivostok, 43 pp. (in Russian). [Кожевников А.Е., Кожевникова 3.В. 1993.
Материалы к флоре Нюкжинского флористического района (Амурская область). ВАаАивосток: БПИ АВО РАН. Аеп. в ВИНИТИ 26.03.1993. № 1372-В93].

Lazkov, G.A. 1998. An overview of section Graminiformes of the genus Silene (Caryophyllaceae) in the flora of Russia. Botanicheskii Zhurnal 83(10): 110-118 (in Russian). [^азьков Г.А. 1998. Обзор секции Graminiformes рода Silene (Caryophyllaceae) во фморе России // Ботанический журнал. Т. 83, № 10. С. 110-118].

Pavlova, N.S. \& T.A. Bezdeleva 1996. Caryophyllaceae. In: Vascular plants of the Soviet Far East. Vol. 8 (S.S. Kharkevich, ed.), pp. 28-125, Nauka, Saint-Petersburg (in Russian). [Пав ова Н.С., Безделева Т.А. 1996. Caryophyllaсеае // Сосудистые растения советского Аамьнего Востока. Санкт-Петербург: Наука. С. 28-125]. 